No 4289 January 12, 1952

Division of the Commonwealth Scientific and Industrial Research Organization, and a number of dredgings off the west coast of Australia for the University of Western Australia. Sounding and dredging were carried out in the Tasman Sea and south-east of New Zealand for the New Zealand Department of Scientific and Industrial Research. A number of Australian and New Zealand scientific workers were carried from time to time and given facilities on the ship, and one Australian biologist, Mr. E. H. M. Ealey, made the whole circumpolar voyage. Help was given to the stations of the Australian National Antarctic Research Expedition on Macquarie and Heard Islands. Stores were landed at Kerguelen for a French expedition, and diesel fuel at Heard Island.

Certain special investigations were included in the programme. One of these was concerned with the Antarctic Convergence, a region of sudden increase in surface temperature between antarctic and subantarctic water masses. This must now be regarded as similar to an atmospheric 'front' in which unstable waves grow into cyclones and anticyclones; but the new observations, while providing evidence of the eddies associated with such frontal developments, gave further indications that the mean position of the convergence remains remarkably constant.

Regular observations on birds made by the Third Officer, Mr. G. H. Selby-Smith, confirm the tendency of all pelagic life in the Southern Ocean to be dis. tributed in circumpolar zones.

In addition to the main survey of the Southern Ocean, observations have been made and repeated along the 90th E. meridian, through the central part of the Indian Ocean, about which there is little other oceanographical information except for a few recent and very useful observations by the French antaretic research vessel, Commandant Charcot. Lines of observations were made also from the Red Sea to the Indian Ocean during June 1950 and in the opposite direction during November 1951. The vertical sections indicate a larger submarine outflow in winter than in summer, but they emphasize the great irregularity of the bottom topography of the region, which makes quantitative comparison difficult. A line of stations was also worked through the Straits of Gibraltar.

During the twenty-month voyage of the Discovery $I I$, Cdr. J. F. Blackburn was in executive command, and the principal scientific officer in charge of the work was Dr. H. F. P. Herdman.

For the next year or two, while the results of the recent voyage are being analysed, the vessel will be employed mainly in research work aimed at furthering our understanding of some of the basic processes which affect the physical conditions and life in the sea. On the physical side, much of the effort will be devoted to studying the processes by which energy is exchanged between the sea and atmosphere, and transported from one area to another or exchanged between shallow and deep layers. It is hoped that a good deal will be done which is of direct interest to all oceanographers, and to save time and expense it will be done as near to the United Kingdom as the conditions most favourable for the experiments can be found. On the biological side, it is expected that much of the effort will be devoted to testing new methods of sampling, and to the study of the habits of some pelagic and bottom-living animals in relation to water conditions, nature and slope of the bottom, and other factors.

\section{FORESTRY IN GREAT BRITAIN}

\section{REPORT FOR THE YEAR 1949-50}

$\mathrm{T}$

WO reports dealing with forestry in Great Britain during the year 1949-50 have been issued by the Forestry Commissioners : the first is the thirtyfirst annual report of the Commissioners* and the other is an account of forest research that took place during the yeart. In their annual report the Commissioners were able to record that agreement had been reached with the representatives of private woodland owners with regard to the conditions under which landowners can dedicate their woodlands to the production of timber and manage them according to a plan of operations satisfactory to the Commissioners, in return for which they recejve certain financial aid from the Government. Objections to details in the contract of dedication had hitherto prevented the landowners' and forestry societies from recommending their members to come into the scheme, and the progress of dedication had been disappointingly slow. Now that these objections have been met, it is hoped that more rapid progress will be made. During the year the response was already apparent in an increase, from 248 to 374 , in the number of estates engaged in preparing plans for the effective management of their woodlands. Further encouragement to private forestry has been given by increasing the planting and maintenance grants and by giving support and encouragement to co-operative associations of small woodland owners for mutual help in managing their woods and marketing their produce. In spite of all efforts to bring about the rehabilitation of the 813,000 acres of woodlands classified as felled or devastated in the Census of Woodlands for 1947, most of which are privately owned, progress is distressingly slow, and the Commissioners feel that, unless there is a considerable improvement within a reasonable time in the rate at which private owners bring their woods into satisfactory production, they will have no option but to use their compulsory powers of acquisition.

Progress in the Commission's work of extending and managing the State forests has continued. The area of land acquired during the year was 109,000 acres, of which 61,000 were classified as "plantable". This brought the total area of land acquired by the Commission to $1,004,000$ acres of "forest land and 664,000 acres of other land", which includes forest nurseries, agricultural and grazing land, and other land unsuitable for planting. During the year, 53,737 acres were planted-an increase of about 10,000 acres on that planted in the previous year. The area thinned was 31,996 acres, and the area clearfelled 1,221 acres. Grants amounting to $£ 12,436$ were made to various universities for educational purposes, and five training schools for foresters were maintained by the Commissioners.

A brief account of the research and experimental work carried out or sponsored by the Commissioners is given in their annual report; but a fuller one appears in the separate report on forest research. This latter is divided into two sections, the first dealing with the work carried out by members of the staff of the Forestry Commission, and the second with work on

* Forestry Commission. Thirty-first Annual Report of the Forestry Commissioners for the Year ending September 30, 1950. Pp. 75. (London: H.M. Stationery Office, 1951.) 28. 6d. net.

$\dagger$ Forestry Commission. Report on Forest Research for the Year ending March 1950. Pp. 126. (London: H.M. Stationery Office, 1951.) 38. 6d. net. 
special problems undertaken for the Commission by universities and other institutions.

Much of the work of the Commission's own research branch is devoted to the trying out of various treatments and techniques on the growth of seedlings and young plants in the nursery and in the forest. Some of the more fundamental problems in connexion with such treatments are dealt with by workers in various institutions. An example of this is the effect of partial sterilization of the soil of established nurseries on the growth and survival of seedlings. It has been found that the residual effects of steriliza. tion by steam and by formalin in the previous year are marked, and experiments are being made with the view of improving the methods of applying formalin to improve the effectiveness of the chemical. J. H. Warcup, of the Botany School, Cambridge, presents some interesting results of the effect of partial sterilization by steam and formalin on the fungal population of the soil at Ampthill Nursery, Bedfordshire, where the response of sitka spruce seedlings to sterilization was very large. Before sterilization, the soils were found to contain more than a hundred species of fungi. In the steamed plots all fungi were killed down to a depth of about twelve inches, and in the formalin plots down to four to six inches. Re. infection started from the surface in about six weeks in the steamed plots and nine weeks in the formalin plots. Re-infection was mainly by Trichoderma viride in the formalin plots. In the steamed plots, Trichoderma was the commonest species to reappear, with Mortierella and Coniothyrium as associates.

A very interesting section of the report is that on forest genetics, by the Commission's geneticist, J. D. Matthews. The ultimate object of the work is, of course, to provide British foresters with supplies of seed which will produce trees of desirable qualities, whether in form, resistance to disease or insect attack, vigour of growth, etc. This is a long-term project which is divided into three stages in its progress towards complete control of parentage. The first step is mass selection. The best stands in the country are being listed by means of the Census of Woodlands for 1947. The older woods are regarded as safe sources of seed, after the obviously bad trees are removed. Younger woods of unknown origin will be tested by observations on plantations formed of their progeny. By this method the parent trees are known only in mass. The second stage is the selection of mother trees. Vigorous and well-formed mother trees have been selected in the best of the older woodlands and plantations, and seed will be gathered from them during several successive years. The progeny will then be tested against a standard race, and 'seed plantations' will be formed from offspring of the best parents. The mother trees are now known, while the fathers are unknown. The third stage is the testing out of outstanding phenotypes by vegetative propagation and controlled pollination. The trees with outstanding genotypic constitution will be included in a series of 'seed orchards' and treated for regular seed production in a similar manner to fruit orchards. Both male and female parents are now of known value. In the report, the progress made with each of the important species used in British forestry is described, and mention is also made of experiments to improve the technique of vegetative propagation. Testing of kinds of stocks and scions for grafting different species, the use of various growth substances to promote the rooting of cuttings, etc., and the search for methods of hastening seed bearing are all receiving attention.

In the section on forest ecology, by J. M. B. Brown, four outstanding beech forests in England are described, with special reference to the natural regeneration. Exposure to wind, which removes the litter and dries the surface soil, hinders or prevents beech regeneration; and generally speaking, regeneration in large gaps is poor or absent, while in smaller openings it is successful. It is clear, from these and other beech woods, that good beech can be grown in Britain under widely different conditions, and one of the conclusions reached is that the $p \mathrm{H}$. of the soil is, of itself, not a decisive factor. Of eighteen of the finest stands of beech in Britain with mean top heights of $100 \mathrm{ft}$. or more, three were definitely on soils with a $p \mathrm{H}$ less than 4.9 (class 1 ) ; two more were in the same class of $p \mathbf{H}$ but on the border-line of the next class; one was in class $2(p \mathrm{H} 4 \cdot 5-5 \cdot 9)$; eight in class $3(p \mathrm{H} 6 \cdot 0-7 \cdot 9)$; and four in class $4(p \mathrm{H}$ more than 8). Attention is, however, directed to the possibility that the influence of the beech canopy on the soil over a period of a hundred and fifty years or more may have caused changes, so that it cannot be assumed that the present $p \mathrm{H}$ of the soil represents the condition in which the forest actually grew up.

It is impossible to mention all the different subjects covered by the report dealing with forest research ; it is especially valuable to forestry workers, but some topics are of interest to biologists and soil scientists generally. In general, the report is valuable because it mentions many of the problems and difficulties with which the British forester is faced and the steps which are being taken to deal with them by sylviculturists, engineers, economists and scientific workers in various fiolds.

T. Thomson

\section{ISOTOPES IN MICROBIOLOGY}

U DER the chairmanship of Dr. A. J. Amos, the Industry organized a symposium "Is Microbiology" which was held at the Institution of Structural Engineers, London, on October 10. In an effort to present the possibilities of tracer technique to those working in both the industrial and academic fields, the papers covered a wide range, from general reviews of the technique and its results to specialized accounts of individual research problems.

Dr. J. C. Boursnell opened the meeting with a paper on "General Aspects of the Use of Radioactive Iso. topes in Biology". Starting from an elementary treatment of the physics and chemistry of radioisotopes, emphasis was laid on the practical consequences of these facts : on the importance of paying attention to counter geometry and its reproducibility, and on the effects of sample thickness when working with soft $\beta$-emitters such as sulphur-35 and carbon-14. So far as precautions against radioactive hazards are concerned, he said there is much to be gained by working rapidly and at a distance from the sample as well as by adequate screening.

Dr. R. Davies reviewed "The Applications of Radioisotopes in Microbiological Chemistry", illustrating the technique of identifying intermediate compounds and of estimating the order of their appearance in a sequence by reference to the work of Calvin and Gaffron on carbon dioxide fixation by Scenedesmus, and to that of Burris and Wilson on 